\title{
ON THE GENESIS OF AIR CELLS IN THE CONCHæ NASALES ${ }^{1}$
}

\author{
JACOB PARSONS SCHAEFFER \\ Cornell University Medical College, Lthaca, N.Y. \\ WITH SEVEN FIGURES.
}

Since the time of Santorini, who apparently was the first anatomist to call attention to the cavities frequently found in the middle nasal conchæ, many conflicting and erroneous hypotheses have been advanced as to the nature and origin of these spaces. Many of the theories are from the pens of clinicians who removed at operation portions of the walls of such cavities that were changed by pathological processes, and then attempted to explain the origin of these spaces from the altered tissue removed.

It is the purpose of this paper to briefly analyze some of the theories extant and, if possible, arrive at the true origin and nature of these cavities - basing the conclusions on a study of the lateral wall of the nasal cavity in the fetus, child, and adult.

These cavities have been variously termed cysts, abscesses, osseous cysts, exostoses, neoplasms, ectasias of the ethmoid bone, air cells, aberrated ethmoid cells, and when large and occurring in the ventral portion of the conchæ mediæ, as conchæ bullosæ.

I have found these cavities, which I consider as normal ethmoid cells, in the concha media, processus uncinatus, and agger nasi. Schaeffer reports an isolated case in the concha inferior, and Bayer found one in the concha superior. The usual seat, however, for these cells is in the anterior half of the concha media, and it is to the cells in this position that the above terms have been applied by various writers. It is not common to find cells in the adult superior conchæ. The reason for this is evident 1909.

'Presented at the 25th session of the Amer. Assoc. Anat., Boston, December, 
when we remember that the adult superior ethmoidal concha are as a rule merely thin lamellæ of bone covering medially the posterior group of ethmoid cells. The most prominent conchx in this position are due to large posterior ethmoid cells which push the median walls of the cells toward the cavum nasi thus forming more pronounced swellings, therefore seemingly larger superior ethmoidal conchæ. It must, however, be remembered that the ethmoidal conchæ are primarily solid appendages of the lateral ethmoidal masses. The developing posterior group of ethmoid cells do not only extend into the lateral ethmoidal masses, but also into the superior ethmoidal conchæ. This extension progresses until the conchæ are represented finally by mere thin lamellæ of bone, covered and lined with mucous membrane. In this sense, portions of posterior ethmoid cells are always conchal cells, just as are those which occupy the middle conchx.

Conchal cells are practically unknown in the concha inferior, because the latter structure is too far removed from the seat of the modifications in the ethmoidal region corsequent upon the formation of the ethmoidal fissures, the structures overhung by the concha media, and the Anlagen of the paranasal chambers.

Santorini (1739) in his "Observationes Anatomice" (p. 89), calls attention to cavitics in the ventral end of the crncha media and claims priority in describing them. He found the cavities both in cadavers and skeletons, but was unable to find ostia for these spaces. He suggests that his failure in findic $g$ openings for the cavities might be due either to the softness of the nucous membrane or smallness of the apertures, and concludes that his successors may find ostia for these spaces. He says: "Ejus tamen inveniendi alterius erit otii, et sedulitatis opus."

Depuytren ('30) speaks of them clinically under the title of "Kyste à parois osseux pris pour un polyp fibro-celleux," and (hantreuil ('69) examined and described a specimen under the title of "Exostose ("elluleuse des Fosses Nasales."

Glasmacher ('84) writes on "Knochenblasenbildung in der Nase," and describes a cell $22 \mathrm{~mm}$. long and $18 \mathrm{~mm}$. wide. He says: 
Was nun die Knochenblasenbildung im Bereiche der Muscheln angeht, so bemerke ich vorab, dass ich diese cbenso wenig, wie im Siebhein für pathologisch ansehe; ihre Wichtigkeit liegt nur in ihrem abnormen Wachsthum.

Schaeffer ('85) speaks of these cells and reports four cases one of which he found in the ventral end of the concha inferiorthe only cell of this concha I have been able to find reported in the literature. I will again refer to this cell in a subsequent paragraph, in an attempt to explain its genesis. He considers the cavities of pathological origin, and in defence of his belief he offers the following:

Zudem gaben die Patienten an, dass sie seit Jahren nach Erkältungen eine Zunahme der Stenose des Nasenganges beobachtet hätten. Dieses Wachsen setzt doch gewisse Reize voraus, die es veranlassen, wenn anders die ganze Knochenblase nicht angeboren ist, was in meinen Fällen nicht der Fall war. Solche Processe müssen wir aber immer unter die pathologischen einrechnen.

He apparently fails to recognize that a normal ethmoidal cell developing in the concha media will gradually lessen the lumen of the nasal fossa. A conchal cell will always begin small, and develop just as the ethmoid cells of the lateral mass but in many cases remains of such size as to cause no trouble, and only when excessively large or diseased is the attention of the clinician directed to it-unless discovered accidentally when exploring this region of the nose for some other cause. The stimulus or irritant of which Schaeffer speaks causing the growth of these cavities is certainly not different from the stimuli which cause the formation of the other paranasal sinuses.

Macdonald ('91) writes on these cells under the title of. "On ('yst and Abscess of the Middle Turbinated Bone." In a previous discussion he "attempted to show that the development of such structures might be analogous to similar tumors of long bones," and in the article under the above title he concludes the theory as "hasty and incorrect"-then advances his osteophytic. theory. Since the latter theory has found its way into many 
articles, also into some text-books, it may not be amiss to quote briefly from his original paper.

The process in all probability begins in an osteophytic periostitis, a condition common in this region, and resulting in a general increase in the size of the bone in every diameter. The free margin being incurved upon itself, from the pathological process just mentioned, will bring it in contact and ultimately in union with the body of the bone. Thus a cavity may become enclosed and sealed at all points by a similar process occurring at the extremities." He further says: "That the above is the correct explanation of the remarkable neoplasms is proved by a microscopical examination of any portion of the cyst wall; on each side of the thin lamina of bone is found a layer of mucous membrane covered with columnar epithelium."

The theory as advanced by Macdonald seems fanciful and to my mind is certainly not the true explanation of the origin of these cavities. In some cases there is a slight lateral and superior curling of the free border of the concha media, thus increasing the extent of the so-called sinus of the concha media, but this sinus is in no way the homologue of conchal cells. Testut and Jacob also refer to this curling of the concha media with reference to cell formation.

According to my specimens, cells invariably have ostia communicating either with the anterior or posterior ethmoid cells, with the inferior ethmoidal fissure (meatus superior) or the infundibulum ethmoidale. Some cells communicate directly with the meatus medius under cover of the concha media. Lothrop's investigation of these cells fully confirms this. He says: "Every cell without exception possesses an ostium." In the second place, Macdonald's theory could not account for the cells having their ostia opening into the meaius superior, nor for those communicating with the infundibulum ethmoidale-yet in my cases fully one-half of the cells open in these positions. The only factor in defense of the theory is that the cavities are lined with columnar epithelium. However, this may be explained in a far more satisfactory manner if we consider the development of these cells as analogous to that of the ethmoid cells of the lateral masses. In fact very many of these cells are merely parts of other ethmoid cells (figs. 4 and 5). 
Knight ('92) reported a case under the title of, "Cyst of the Middle Turbinate." He mentions two possible theories, viz: (a) the "result of a rarefying osteitis," (b) that of Macdonald as given above. In his text-book ('03) he says:

In the majority of cases it doubtless results from a rarefying osteitis inducing absorption of the interior of the body of the bone.

This latter theory is not permissible when we recall that these cells or cavities are lined with mucous membrane similar to that of the ethmoid cells of the lateral masses.

Reardon ('98), writes on "Osseous Cysts of the Middle Turbinate." He thinks the cavities are either ectasias of the ethmoid which, as the ethmoid develops, become separated from it completely or incompletely; or are aberrated ethmoidal cells which developed in the conchæ (Heymann's theory).

It is easily understood why many clinicians continually refer to these cavities as cysts, osseous cysts, abscesses, etc., because they generally have their attention directed to them only when they are diseased, unless the air cell becomes very large without disease and leads to symptoms of obstruction and pressure. They then attempt to explain the genesis of these primarily normal cells from the pathological condition found.

It must be remembered that these conchal cells, like any of the ethmoid cells or other paranasal sinuses, may become the seat of an empyema or mucocele, and enlarge, because the ostia of these cells are invariably placed at the highest points of the cavities and very disadvantageously placed as drainage openings - a fact easily understood if we consider their development. The existence of air cells in the conchæ, etc., is certainly not the result of an empysma or rarefying osteitis, but because these cells are normally found in these positions, they may become the seat of pathological conditions just as any other cell of the ethmoid labyrinth.

Zuckerkandl refers to the distension, by an air cell, of the ventral extremity of the concha media as, "concha bullosa."

Lothrop after studying a large number of these cavities in adult specimens concludes that they are ethmoid cells-a view 

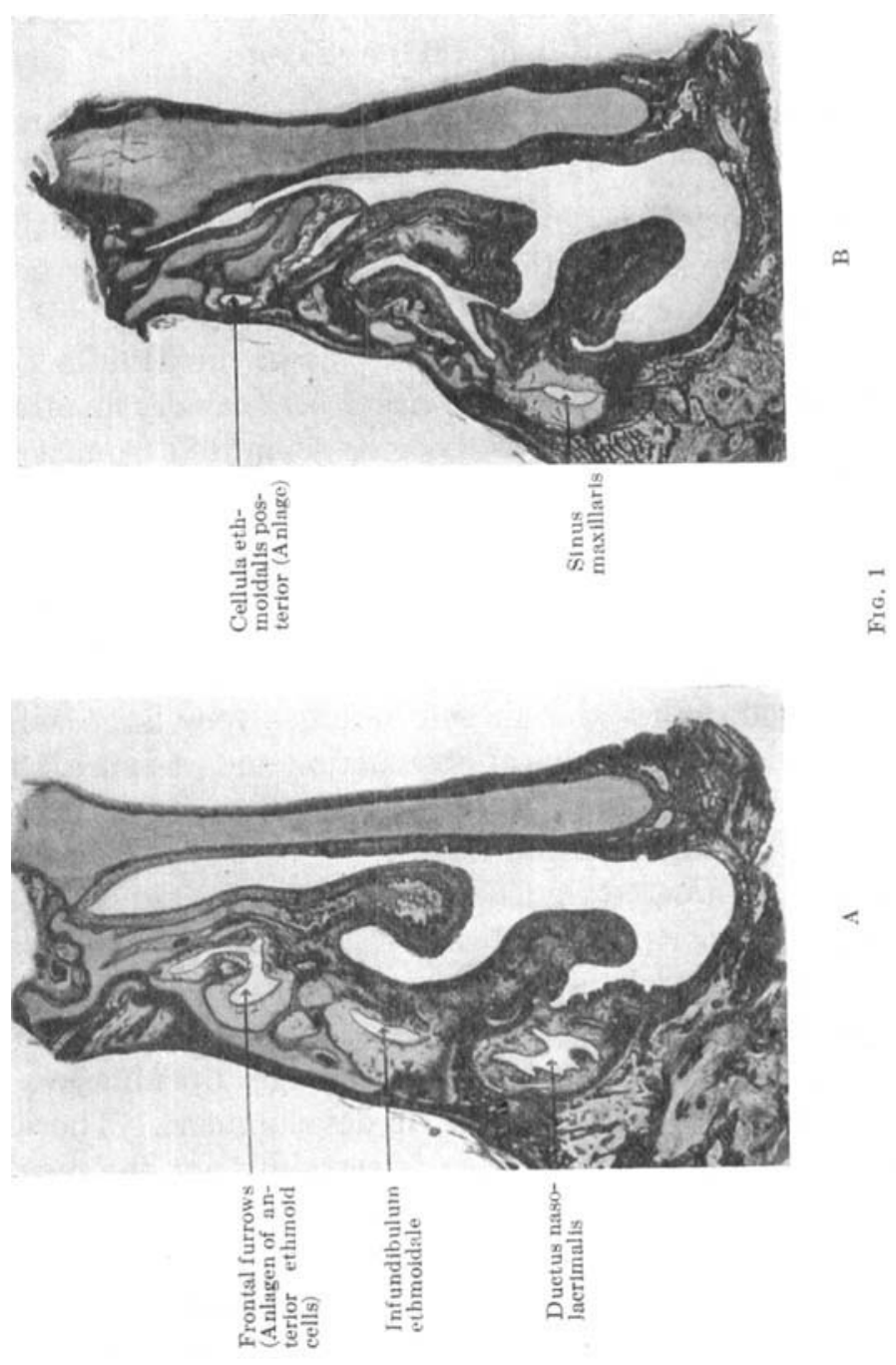

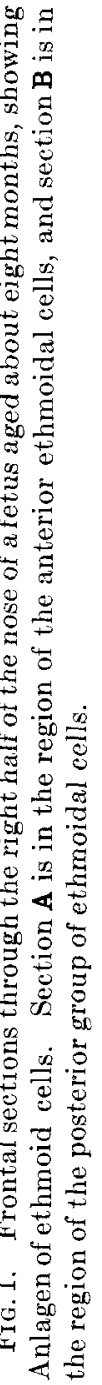



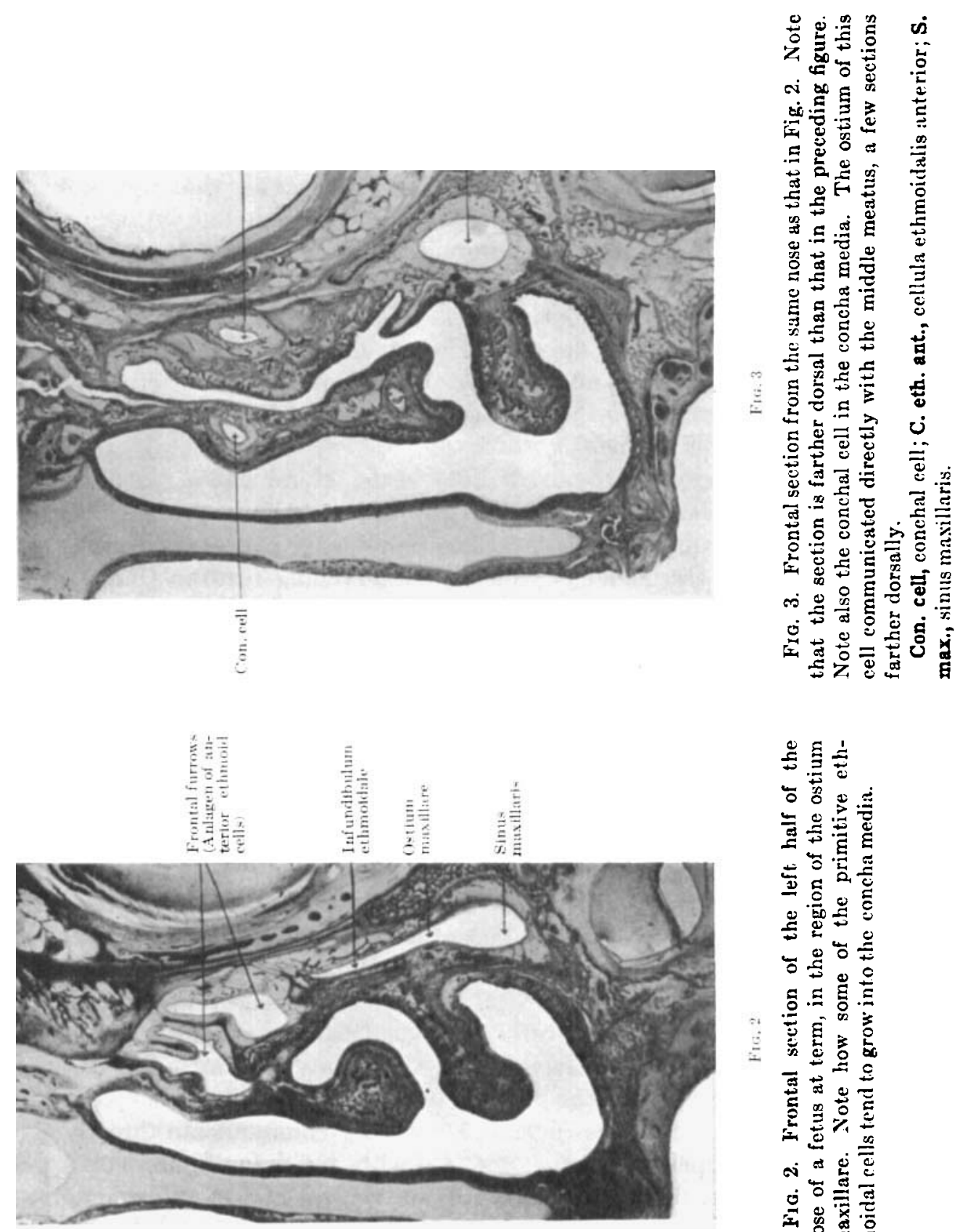

号薯

영

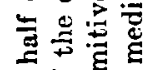

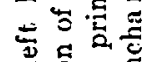
-

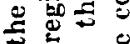
$\div 0$ -

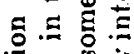
ํ.

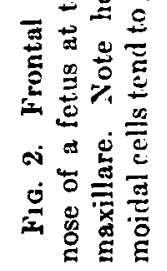


also held by Shambaugh, who speaks of them as "anatomical variations of ethmoid cells."

In order to better understand these cells and see that they are nothing other than ethmoid cells, it is essential that we briefly consider the origin of the ethmoid labyrinth. The location of these cells appears less abnormal when we recall that the ethmoidal conchæ and uncinate processes are merely appendages of the lateral ethmoidal masses. There is no reason, therefore, why ethmoid cells should not at times, in the formation of the ethmoid labyrinth, grow into these appendages just as they grow into the lateral ethmoidal masses.

According to my reconstructions of the lateral wall of the nasal cavity of different aged fetuses, the primitive ethmo-turbinal fold, with its subsequent modifications is not only concerned in producing the ethmoidal conchæ and intervening furrows (meati), but also the structures operculated by the middle nasal concha: viz., the processus uncinatus, the bulla ethmoidalis, the hiatus semilunaris, and the infundibulum ethmoidale. These modifications are also intimately related with the Anlagen of the paranasal sinuses.

The posterior group of ethmoid cells are primarily constricted from, or are direct extensions of, the furrows separating the primitive ethmoidal conchæ, and the anterior group develop from the preformed accessory furrows of the middle meatus-hence are in relation with the grooving and structures found in this location.

Frontal sections of the fetal nose before birth (fig. 1) already indicate the Anlage of the ethmoid labyrinth, and at term it is comparatively well advanced (fig. 2). In this connection it is an interesting fact that the ostia of conchal cells invariably communicate directly or indirectly with the points at which the ethmoid cells developed their Anlagen. These cells are either parts of other ethmoid cells (figs. 4,5), or they communicate directly with the superior meatus (fig. 4), with the infundibulum ethmoidale (fig. 6), or directly with the ventral end of the middle meatus (fig. 5). The ostia in the latter case are on the lateral wall of the concha media. 
ON THE GENESIS OF AIR CELLS IN THE CONCHA NASALES 175

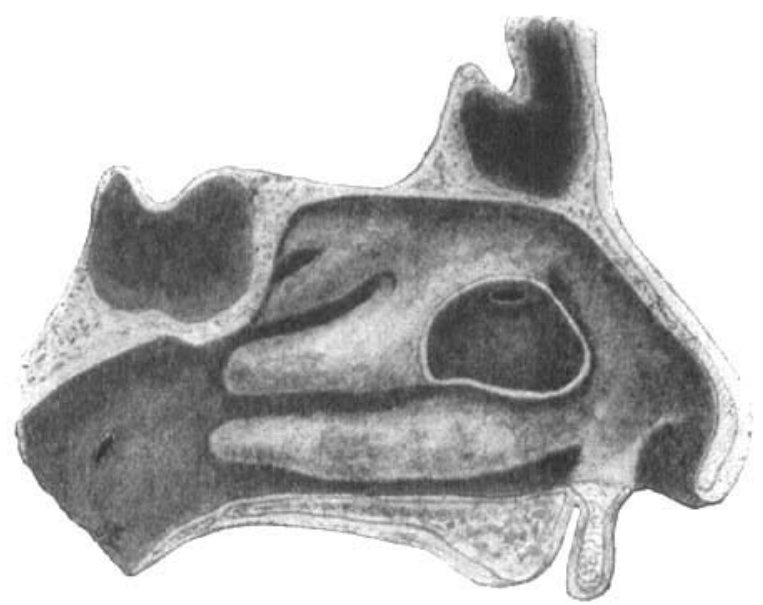

FIt. 4. Drawing from a specimen of the lateral nasal wall. The cell extending into the agger nasi and into the processus uncinatus communicates with the infundibulum ethmoidale. Note that the ethmoid labyrinth is largely replaced by a very large bullous cell extending into the concha media and communicating with the ventral extremity of the meatus superior.

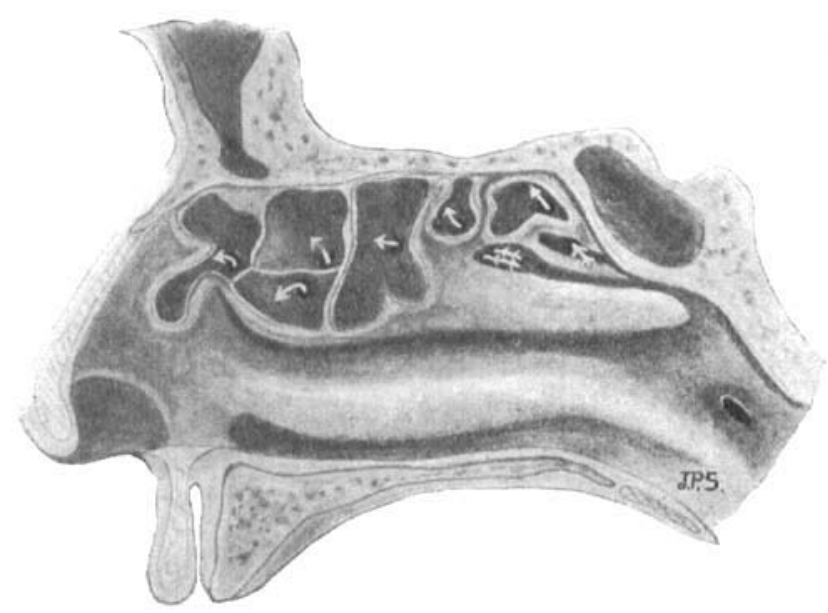

Fig. 5. Drawing from a specimen of the lateral nasal wall. The arrows indicate the ostia of the several cells. Note that one of the cells which communicates with the meatus superior extends into the concha media. Note also the cell in ventral extremity of the concha media with an independent ostium communicating directly with the meatus medius.

THE ANATOMICAl. RECORD VUL. 4 No. 4. 
Although the Anlagen of the ethmoid cells are primarily constrictions from the nasal fossæ, yet the extension and development of these cells depend upon the simultaneous processes of growth (of the sacs) and resorption (of surrounding tissue). In this manner, as age advances, the cells extend farther and farther into the lateral masses of the ethmoid bone, and in the adult are completed by the articulation of the ethmoid bone with the frontal, lacrimal, sphenoid, maxillary, and palate bones. These developmental processes are doubtless in some cases carried further than in others, hence the extension of ethmoid cells not only farther into the lateral masses of the ethmoid bone, but also into its appendages, such as the ethmoidal conchæ and uncinate processes. Ethmoidal cells also at times extend into the agger nasi and encroach upon the sinus frontales and sphenoidales.

A reference to figs. 4 and 5 shows the extension of the inferior ethmoidal groove (meatus superior) not only into the lateral mass but also into the concha media, thus forming conchal cells which are merely parts of the lateral mass cells. At first thought it may seem difficult to account for the conchal cells having their ostia opening inferior to the attachment of the concha media, either into the middle meatus or the infundibulum ethmoidale (figs. 4, 5, 6). However, when we remember the great modifications of this portion of the middle meatus overhung by the concha media, consequent upon the formation of the structures found here, and that the anterior group of ethmoid cells have their origin in this position, it is not difficult to see how some of these cell-Anlagen may extend not only into the lateral mass of the ethmoid bone, but also into the uncinate process, the concha media, and the agger nasi (figs. 4, 5, 6). Fig. 3 shows a small cell already present in the concha media of a fetus at term. Of course most conchal cells must necessarily appear comparatively late in the formation of the ethmoid labyrinth, since the positions they occupy with reference to the ethmoid cell Anlagen are relatively far removed. The extensions into the conchæ, etc., would, therefore, in most cases be delayed-probably until puberty, or even later, when the ethmoid labyrinth reaches its full development. This explains Knight's statement: "Children seem to be exempt. None of my patients was under 20 years of age." 


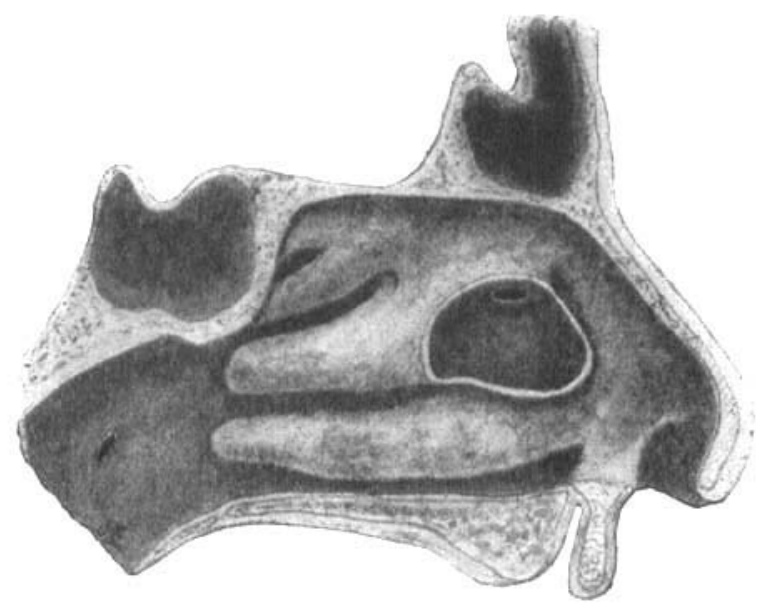

FIG. 6. Drawing from a specimen of the lateral nasal wall. Note the large cell in the concha media communicating with the infunidbulum ethmoidale.

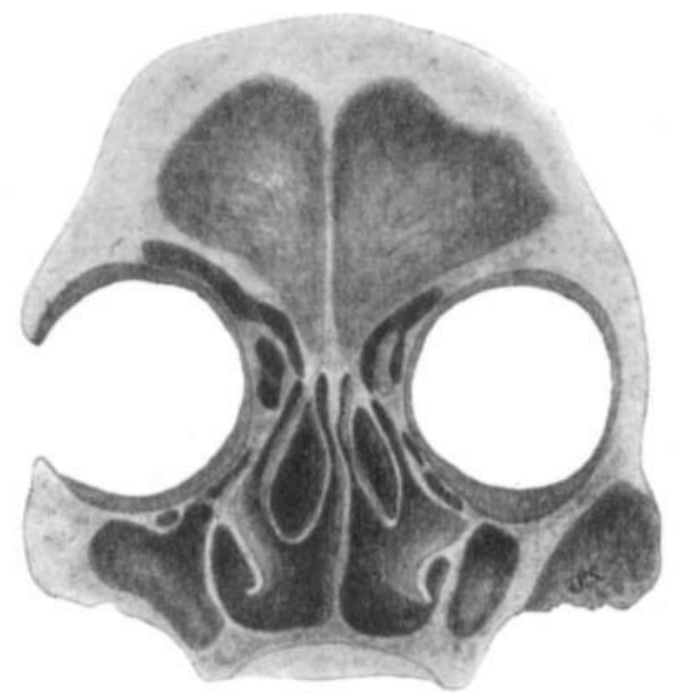

Fia. 7. Drawing of a frontal section through the head of an adult. Note the bilateral conchal cells in the middle nasal conchr. 
Figs. 4 and 5 show the extension of ethmoid cells into the agger nasi. There is no reason why cells in this location should not extend farther, and finally reach and occupy the ventral end of the concha inferior. Such an extension would explain Schaeffer's cell of the ventral end of the inferior nasal concha.

Occasionally multiple cells are present, separated by thin partitions-each cell having an independent ostium, or in communication with either a cell of the anterior or one of the posterior group (fig. 5). Both conchæ mediæ of the same individual may contain cells (fig. 7), or one may be free of such cavities and the other contain one or more cells. Figs. 6 and 7 show the bullous type of cells-termed by Zuckerkandl "conchæ bullosæ."

Sex apparently does not have any bearing on the development. of conchal cells, and they are about equally divided as to whether the ostia open superior or inferior to the attached border of the concha media.

The cells found in the conchæ, uncinate processes, agger nasi, and those extending into the frontal and sphenoidal sinuses, do not differ in any manner from the ethmoid cells of the lateral masses. The mucous membrane lining these conchal cells is extremely thin, but corresponds in its general structure with that lining the other ethmoid cells - unless changed by a pathological process.

Santorini thought the condition quite common, but says he should not venture to say that the condition is constant. He apparently regarded these cells as much more common than they really are. According to Reardon, Zuckerkandl observed them eight times in 172 skulls. Knight says that Zuckerkandl "found them thirty-six times in 200 post-mortem examinations." Lothrop found them in 9 per cent of all cases, and 11 per cent of the writer's specimens showed cells in the locations mentioned in a previous paragraph. The latter conclusions are based upon an examination of 150 adult nasal fossa. 
ON THE GENESIS OF AIR CELLS IN THE CONCHA NASALES 179

CONCLLSIONS

1. The cells found in the concha nasalis media, agger nasi, and processus uncinatus are true ethmoid cells, because:

(a) They differ in no manner from the cells of the lateral ethmoidal masses;

(b) Their ostia are invariably located at the points from which the ethmoid cells developed their Anlagen;

(c) They are frequently merely portions of lateral mass cells.

2. The cells invariably have ostia which communicate either with the superior meatus, with the ethmoidal infundibulum, or directly with the middle meatus.

3. The conchal cells may become the seat of a mucocele, abscess, etc., just as may the cells of the lateral ethmoidal masses, but to say that these cells owe their genesis to such pathological conditions is erroneous.

4. The so-called middle conchal sinus formed by the lateral and superior curling of the free border of the concha media is not homologous with, nor analogous to a conchal cell; nevertheless in some cases it may retain fluid in its hammock-like fold. The majority of conchæ mediæ, however, do not show this sinus, and when present it is, as a rule, of minor importance.

\section{BIBLIOGRAPHY}

Chantrelil. Bul. Soc. Inal de Paris, vol. 44, p. 83. 1869

Depirtrex. Clinique Paris, vol. 11, pp. 17t-179. 1830

(iLAsiacher. Knochenblasenbildung in der Nase. Berliner Klin. Wockensehr., $1884 \quad$ vol. 21, pp. $571-573$.

Knight, C. H. Cyst of the middle turbinate. The New York Med. Journal, 1.592 rol. 55, p. 309.

1903 Diseases of the nose and throat, pp. 44-45.

Lотнвор, H. A. The anatomy of the inferior ethmoidal turbinate bone with 1903 particular reference to cell formation. Amuals of Surgery. vol. 38, p. 244.

Macdonald, Greville. On cyst and abscess of the midlde turbinated bone. 1891 The Lancet, vol. i, 69th yr., p. 13 it.

REARDox. T. J. Osseous cysts of the middle turbinate. Boston Med. and 1898 surg. Jour., vol. 129 , p. 569. 
Santorini, Dominici Joannes. Observationes Anatonicæ, pp. 88-89. 1739

Schaffrer, Max. Knochenblasenbildung in der Nasenhöhle. Chir. Erfah1885 rungen der Rhinol. and Laryngol, pp. 11-13.

Shambaugh, Geo. E: The construction of the ethmoid labyrinth. Trans. 1907 Amer. Laryngol. Assoc., pp. 110-121.

Testut and Jacob. Traité D'Anatomie 'Topographique. Tume Premier, p. 433. 1905

Zuckerkand, E. Die untere Siebbeinmuschel (mittlere Nasenmuschel), Nor1893 male und pathologische anatomie der Nasenhöhle und ihrer pneumatischen Anhänge. Bd. i, pp. 62-6j 